\title{
Hotspot Ecosystem Research on Europe's Deep-Ocean Margins
}

BY PHILIP P.E. WEAVER, DAVID S.M. BILLETT, ANTJE BOETIUS, ROBERTO DANOVARO, ANDRÉ FREIWALD, AND MYRIAM SIBUET

Europe's deep-ocean margin stretches over a distance of $15,000 \mathrm{~km}$ along the Atlantic Ocean from the Arctic to the Iberian margin and from western to eastern Mediterranean, and to the Black Sea. The margin extends from the shelf edge at about $200 \mathrm{~m}$ depth until about $4000 \mathrm{~m}$ depth where the abyssal plain or oceanic basins begin, and covers three million square kilometers, an area about onethird of that covered by Europe's landmass. Most of this deep-ocean frontier lies within Europe's Exclusive Economic Zone (EEZ) and is therefore of direct interest for the exploitation of biological, energy, and mineral resources. A major European policy aim is to develop these resources in an ecologically sustainable manner. This requires a profound knowledge of the structure and dynamics of ocean margin ecosystems incorporating a wide variety of complex environments, such as deep-sea corals, cold seeps, and canyons. The knowledge re- quired must be generated in an integrated way that ties research on biodiversity and biological processes intimately to the physical factors that control ecosystems (geology, sedimentology, physical oceanography, biogeochemistry). In addition, it is important to set present-day ecosystems in an historical framework by studying the sediment record to determine long-term environmental changes and the potential response of ecosystems to global change over decadal to millennial scales. Changes due to large-scale natural forcing (e.g., climate oscillations, sea-level change) or to more local human effects (e.g., resource exploitation, inputs of pollutants and nutrients) must be distinguished from each other before man's activities make this distinction impossible (Danovaro et al., 2001). In some areas, notably deep-water coral reefs, man's impact on the environment has already been considerable (Freiwald et al., 2004).
A consortium of 45 partners, including 9 small companies from 15 European countries (Box 1), are being funded under the European Union's Sixth Framework Research Programme to study benthic ecosystems on Europe's continental margins. The project-HERMES (Hotspot Ecosystem Research on the Margins of European Seas)_-will begin in early 2005. It will study "hotspot" ecosystems-discontinuous environments that are constrained by chemical, physical, topographic, and geological factors and that contain a wealth of unknown species that thrive in insular habitats. Determining the distribution as well as the resilience of these ecosystems is fundamental to producing plans for their sustainable management.

HERMES takes a major leap forward from previous, smaller research projects because it coordinates research efforts along the whole European margin. HERMES will integrate knowledge and 
Philip P.E. Weaver (ppew@soc.soton.

ac.uk) is leader of the HERMES project and Professor, Southampton Oceanography Centre, United Kingdom. David S.M. Billett is Benthic Biology Group Leader, Southampton Oceanography Centre, United Kingdom.

Antje Boetius is Professor, Max Planck Institute for Marine Microbiology, Bremen, Germany. Roberto Danovaro is Professor, Dipartimento di Scienze del Mare, Università Politecnica delle Marche, Ancona, Italy. André Freiwald is Professor, Institut für Paläontologie, Universität ErlangenNürnberg, Erlangen, Germany. Myriam Sibuet is Director, Department of Deep-Sea Environment, Institut français de recherche pour l'exploitation de la mer (IFREMER), Plouzané Cedex, France. new data in different marine sciences (geology, physical oceanography, chemistry, and biology, including microbiology). Results from a number of contrasting locations along the margin and within different biogeochemical settings will be compared, using common methods. An integrated approach is important because many of the management issues relate not to just one nation's marine estate, but to the whole European margin. Management plans are needed that cross national boundaries. Therefore, a science program is needed that takes this largescale view into account. In addition, work on the hotspot ecosystems requires sophisticated technology, such as remotely operated vehicles (ROVs), autono- mous underwater vehicles, and lander in situ instrumentation, which are available only in some European member states.

HERMES is one of the largest marine science projects in Europe, and as such it is expected to have a high profile with a high impact on education of young scientists. HERMES will link with related international projects such as Census of Marine Life, the U.S. National Oceanic and Atmospheric Administration's Undersea Research Center for the North Atlantic, the U.S. National Science Foundation's Microbial Observatories Program and Frontiers in Integrative Biology, and the Canadian Geoscience for Oceans Management.

\section{BOX 1: HERMES CONSORTIUM}

\section{Academic Partners}

- Alfred Wegener Institute, Germany

- Consejo Superior de Investigaciones Cientificas, Spain

- Consiglio Nazionale delle Richerche (CNR)

- Istituto de Scienze Marine (ISMAR), Italy

- Consorzio Nazionale Interuniversitario per le Scienze del Mare, Italy

- Friedrich-Alexander University ErlangenNuremberg, Germany

- GeoEcoMar, Romania

- Hellenic Centre for Marine Research, Greece

- Institut Français de Recherche pour I'Exploitation de la Mer (IFREMER), France

- Institut Scientifique, Morocco

- Institute of Marine Research, Norway

- Instituto Hidrografico, Portugal

- International University of Bremen, Germany

- Istituto Nazionale di Oceanografia e di Geofisica Sperimentale, Italy

- Centre National de la Recherche Scientifique (CNRS) - Centre de Formation et de

\section{Recherche sur l'Environnement Marin} (CEFREM), France

- Liebniz-Institut für Meereswissenschaften (IFM-GEOMAR), Germany

- Max Planck Institite for Marine Microbiology, Germany

- National University of Ireland Galway

- Royal Netherlands Institute for Sea Research

- Scottish Association for Marine Science, United Kingdom

- Natural Environment Research Council, Southampton Oceanography Centre, United Kingdom

- The Intergovernmental Oceanographic Commission of UNESCO

- The Netherlands Institute for Ecology

- Université de Bretagne Occidentale, France

- Université Pierre et Marie Curie

- University of Aberdeen, United Kingdom

- University of Aveiro, Portugal

- University of Barcelona, Spain

- University of Birmingham, United Kingdom
- University of Bremen, Germany

- University of Goteborg, Sweden

- University of Liverpool, United Kingdom

- University of Southampton, United Kingdom

- University of Tromsø, Norway

- University of Wales Cardiff, United Kingdom

- Yasar University, Turkey

\section{Business Partners}

- ArchimediX, Germany

- Challenger Oceanic Systems and Services, United kingdom

- Median SCP, Spain

- MMCD Multimedia Consulting $\mathrm{GmbH}$, Germany

- Olex AS, Norway

- Praesentis S.L., Spain

- Proteus SA, France

- Volcanic Basin Petroleum Research AS, Norway

- Jobin Yvon S.A.S., France 


\section{IDENTIFICATION OF "HOTSPOTS"}

Ecosystems on continental margins that are least understood include canyon ecosystems, microbially driven ecosystems in anoxic environments, and chemosynthetic ecosystems associated with methane seeps. In addition, deep-water coral ecosystems require urgent study as they occur at depths where deep-water trawlers are active; these trawlers have already caused considerable destruction of these fragile habitats. Despite their fragmented distribution, these ecosystems have important functions: (1) cold seep and anoxic ecosystems act as filters for methane and sulfide, (2) deep-water corals play a role in $\mathrm{CO}_{2}$ sequestration, and (3) canyon systems are preferential conduits and deposition centers for carbon and are thought to be important nursery areas for deep-water fish stocks. HERMES will also study open-slope ecosystems adjacent to the hotspots so that biological systems can be studied in the context of the wider continental slope. Here, large environmental gradients (temperature, pressure) and major environmental perturbations, such as recent landslides, play an important role.

\section{Cold-Water Coral Ecosystems and Carbonate Mounds}

Cold-water coral ecosystems create reeflike frameworks and contribute to the formation of carbonate mounds. The colonial stone corals Lophelia pertusa and Madrepora oculata (Figure 1) occur on the deep shelves along $4500 \mathrm{~km}$ of the northwestern European continental margin, and in Scandinavian fjords. Despite intense mapping, progress achieved during the Fifth Framework Programme's ACES, ECOMOUND, and GEOMOUND projects, and various national seabed mapping surveys off Norway and Ireland, researchers still do not know how many reefs and mounds exist. (ACES is the Atlantic Coral Ecosystem Study. ECOMOUND is Environmental Controls on Mound Formation along the European Continental Margin. GEOMOUND is a project focusing on the geological evolution of giant, deep-water carbonate mounds off western Ireland

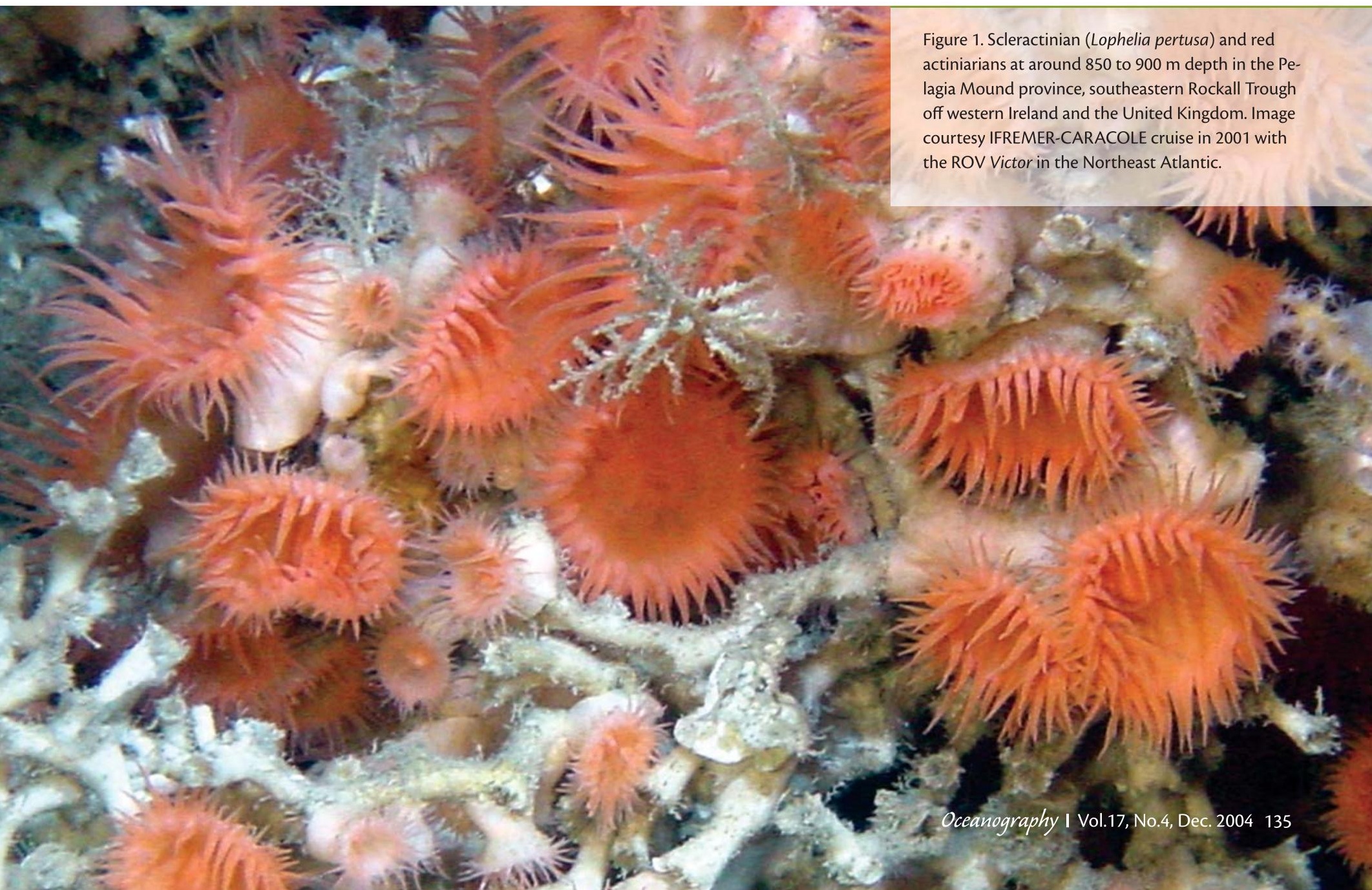


Determining the distribution as well as the

resilience of these ecosystems is fundamental to producing plans for their sustainable management.

and the United Kingdom [see Mienert et al., this issue].) Because the coral colonies are intensely calcified, they provide a three-dimensional complex habitat for a vast number of associated species that live permanently, or temporarily, within the coral ecosystem. With this large latitudinal spread of the coral ecosystem, we can analyze ecosystem response to different trophic regimes, comparing seasonally eutrophic, high-latitude settings with more meso- to oligotrophic sites further south in the Northeast Atlantic and the Mediterranean Sea. These comparative studies will be carried out by assessing biodiversity trends (taxonomy and molecular genetics) and trophic food webs (biochemistry). Site-specific life-history studies will be performed on the coral skeletons using environmentally sensitive trace elements and stable isotopes. In order to define the physical forcing factors and the quality and quantity of carbonflux rates, targeted long-term experiments using benthic landers equipped with conductivity-temperature-depth (CTD) probes, Acoustic Doppler Current Profilers (ADCPs), current meters, particle traps, and time-lapse cameras, will be deployed in a number of hydroacoustically mapped and ROV-inspected coral sites. In some locations, cold-water coral associations thrive in close proximity to hydrocarbon fluid-flow environments, such as in or near active pockmarks on the Norwegian Shelf, or on the flanks of mud volcanoes in the Gulf of Cadiz. These areas are prime sites for addressing whether coral communities are associated with seabed geosphere processes.

Cold-water coral ecosystems are also important environmental archives of global change and shorter climatic oscillations, but hitherto have been poorly exploited for this purpose. Unlike shallow-water tropical reefs, the cold-water corals lived at bathyal depths beyond the glacial-driven amplitudes of sea-level low stands. Moreover, this type of coral ecosystem thrives in the flow of the intermediate water mass, which provides a unique opportunity to measure mixing processes between the productive surface waters and the deeper ocean environment. Intense radiocarbon or U-Th dating techniques of fossil corals will elucidate the response of bathyal coral ecosystems to climate-related changes, such as circulation patterns, hydrodynamic regimes, and surface-water productivity. We know now that cold-water corals were only found south of Gibraltar during the Last Glacial Maximum (22,000 years to 14,000 years before present), but extended to occupy the vast Norwegian continental shelf shortly after the Termination IB period ( 8500 years before present). During this period, corals expanded their distribution throughout the western and central Mediterranean, but they have become less abundant since then.

Since the mid-1980s, the socio-economic value of cold-water coral ecosys- tems has risen tremendously. In many areas of the European EEZ, major trawling areas overlap with occurrences of coral ecosystems (Freiwald et al., 2004). Trawling over cold-water coral reefs with demersal trawls is comparable to forest clear-cutting, but the coral systems might take much longer to recover. The documentation of ongoing damage to the benthic ecosystem and a risk analysis of planned human activities along Europe's continental margin is a major issue that will be addressed by the HERMES research consortium.

\section{Cold Seep and Microbially Driven} Ecosystems

Microbes occur in every niche in the ocean and comprise a significant part of the global biomass. In some continental margin ecosystems, they dominate life almost exclusively, generating a great diversity of bacteria, archaea, and some single-cell eukaryotes. Natural chemical laboratories occur in areas of subsea discharge of fluids and gas (e.g., methane) (Boetius et al., 2000). The free living and symbiotic microbial communities associated with some invertebrates are nourished by the chemical energy rising from these sources and form the basis of cold seep ecosystems (Sibuet and OluLe Roy, 2003). These often take the form of dense and endemic benthic communities, in which the high production of organic carbon sustains large size or typical animals and very high biomasses. In high methane flux areas, the benthic biomass produced through chemosynthetic processes can be 1,000 to 50,000 times greater than the deep-sea biomass resulting indirectly from photosynthetic production. The remarkable abundance 


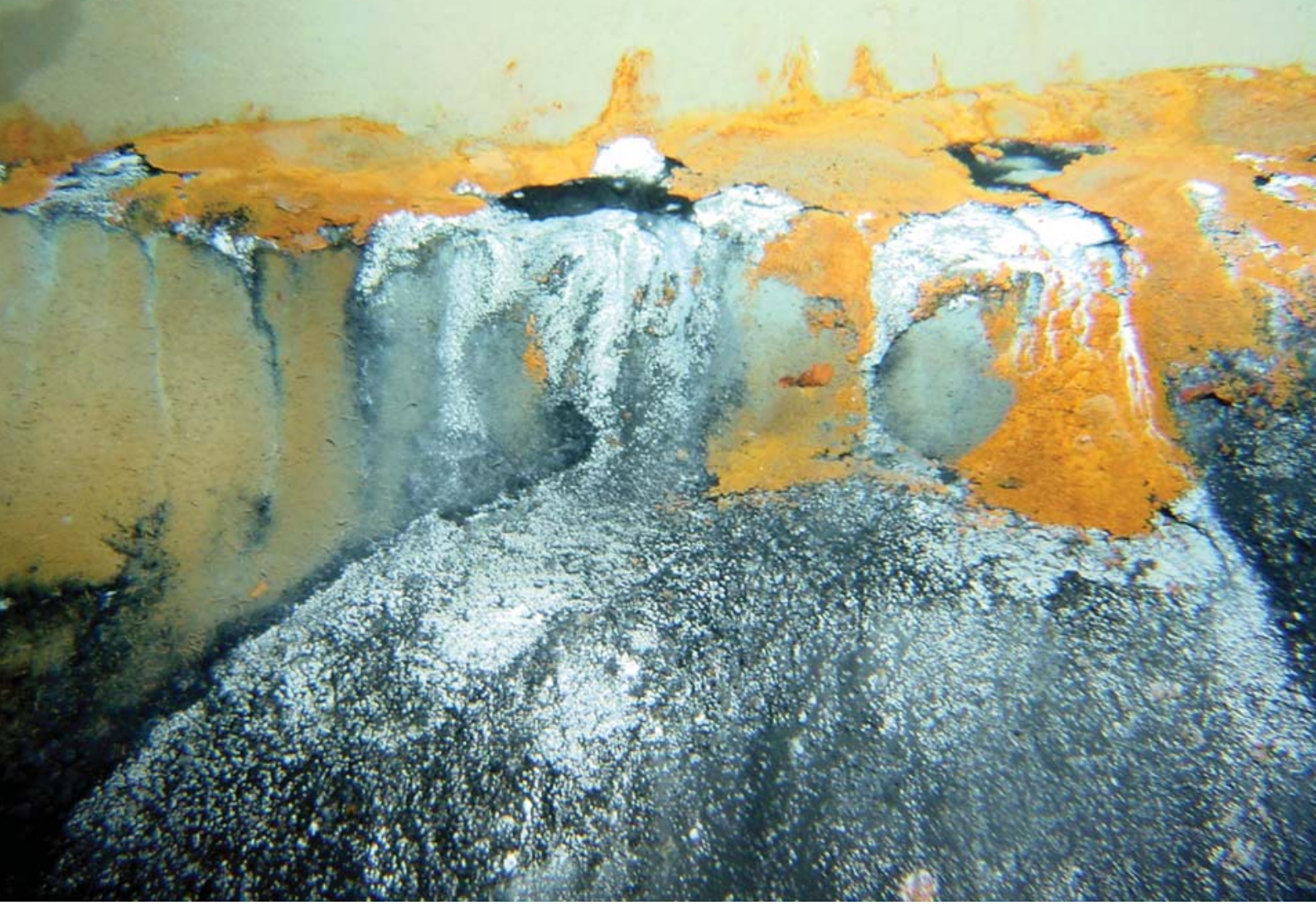

Figure 3. Microbial biofilms at a cold seep on the Nile deep-sea fan at 2970 $m$ depth. Image courtesy IFREMER-Nautinil cruise (EUROCORE Euromargin project MEDIFLUX) in 2003 with the manned submersible Nautile in the eastern Mediterranean.

logical structures, and are excellent target areas. Recent geomicrobiological research provides evidence for a variety of these ecosystems, which hold a great diversity and biomass of bacteria and archaea (Boetius et al., 2000). Our current understanding of the distribution of methane within sediments, both regionally and on small scales, is poor. The relationship of hydrate to microbial activity, and to venting and support of chemosynthetic communities, is also poorly known. Additionally, gas hydrates pose a potential threat because submarine landslides could be initiated by their rapid melting. This process would also release large volumes of the greenhouse gas methane into the atmosphere. We will monitor fluid release at a variety of sites (including some known, overlying areas of methane hydrate), to determine (1) the contribution of this source of carbon to the hy- drosphere, (2) its rate of use by seabed communities, and (3) the variation in this fluid escape with time. HERMES will integrate geological techniques with biogeochemical flux measurements and biological data to achieve a quantitative understanding of ecosystems.

The aim of future research on these ecosystems is to understand (1) fluid generation mechanisms and how the flux rates vary through zones and time, (2) the historical development of mud volcanoes and pockmarks which include the characterization and dating of authigenic carbonates and associated sediment, and (3) how physical and chemical characteristics of fluids in the sediment, crust, and at the sediment-water interface control the community diversity, the dynamics of the system, and the biological production based on chemosynthesis through free and symbiotic bacteria.

\section{Canyon Ecosystems}

Canyons are deep incisions of the continental shelf and slope. They dissect much of the European ocean margin. Were these canyons on land, they would present some of the most dramatic mountain scenery in the world. Hidden by the ocean, they have been ignored. This is largely because of difficulties in exploring their complex terrain. Yet, canyons are known as (1) hotspots of high faunal biomass, (2) major pathways for transportation and burial of organic carbon in the oceans, and (3) fast-track corridors for material transported from the land to the deep sea (Rogers et al., 2003). It is only now-with advances in technology such as ROVs, swath bathymetry, side-scan sonar, and definitive position-fixing systems - that progress is being made in their study. Some canyons are closely connected to major river out- 
flow systems while others funnel large quantities of sediment from the continental shelf into deep water. Canyons act as temporary depots for sediment and carbon storage. However, rapid, episodic flushing of canyons may mobilize large amounts of sediment carrying it to the abyss and overwhelming benthic ecosystems over a wide area (Thomsen et al., 2003). The frequency of these potentially catastrophic events and the fluxes of particles produced are largely unknown, as are the rates of recolonization and restoration of the canyon ecosystems.

Canyons are complex systems in terms of their hydrography, sedimentology, biogeochemistry, and biology. As more is learned about canyons, it becomes increasingly obvious that there is great variability both within individual canyon systems and between different canyons. Individual canyons have very different environmental characteristics that determine the diversity and the ecology of their fauna (Vetter and Dayton, 1998). This makes it difficult to reach generalizations that will be useful in creating policies for whole ecosystem management, without (1) a concerted effort to compare canyons from different biogeochemical provinces and different topographic settings and (2) coordinated, multidisciplinary projects relating the fauna to the environmental variables that regulate their distributions.

HERMES will study specific canyons in four different biogeochemical provinces: (1) off Ireland, (2) off Portugal, (3) in the western Mediterranean, and (4) in the eastern Mediterranean. The physical processes in canyons will be studied with particular regard to the transport of particulate material and the distribution

of key fauna. Physical processes in and around canyons can be highly complex and are difficult to study because many of the more important processes are episodic in nature. Understanding physical processes, such as the focusing of internal waves and storm events, are critical in understanding the production of nepheloid layers by resuspension and the enhancement of primary productivity at canyon heads. There is great temporal variation in the creation of nepheloid layers (from days to years), and fluxes can vary over several orders of magnitude.

Our view of biological processes in canyons has changed considerably in the last few years because of the increased use of submersibles and ROVs. The results indicate the importance of various zooplankton groups acting as a link to fish and mammal populations. The species and their abundances differ from canyon to canyon and appear to be related to downward particle fluxes, topography, and the hydrographic features of individual canyons. Canyons appear to be important in the channeling of macrophyte debris, which may

\section{So far, marine ecosystem assessment suffers from a lack of models integrating biology into element cycles and global change issues.}

have a significant effect on the relative abundance of some species. Few studies of the chemistry of canyons have been carried out, even though canyons play a crucial role in the redistribution of carbon and anthropogenic materials derived from marine primary production and terrestrial runoff. Because canyons (the Continental Slope Stability program) (see Mienert et al., this issue), the causes of seabed instability (particularly landslides) are still not fully understood, and, yet, they pose significant threats to coastal communities through associated tsunamis. For example, the Storegga slide and its resulting tsunami devastated 
coastal communities in Norway, Scotland, and Denmark 8,200 years ago.

Slopes are ideal systems for investigating benthic patterns: the decrease of benthic faunal biomass with increasing depth is one of the best-known patterns in marine ecology. However, there is considerable variability in the abundance and biomass of benthic fauna along the same isobath, and upwelling regions and coastal trenches may lead to "hotspots" of life. It is becoming increasingly evident that we are not able to predict the spatial distribution of deep-sea benthic ecosystems using a limited set of variables. Deep-sea hotspots of benthic biomass suggest that the "paradigm" of decreasing life with increasing depths is not universal and that detailed knowledge is needed to explain anomalies.

Determining spatial heterogeneity is one of the most significant challenges in the study of continental margin ecosystems. The distribution of benthic organisms on macro-scale (>1000 km) is assumed to be dependent on physical parameters (temperature, water masses), while at mesoscale (1-100 km), export of primary production, sediment heterogeneity, oxygen availability, and catastrophic events play major roles. At smaller scales the distribution of benthic organisms is influenced by interactions between organisms (competition, predation) and microhabitats (sediment micro-topography, chemical interactions, food distribution). Several key questions remain unanswered: Is spatial variability of deep-sea benthos dependent upon the characteristics of the system? Is the mosaic of distribution (and community composition) of deep-sea fauna explained by the biotic/abiotic interaction at a specific spatial scale? Is energy source a factor relevant at all spatial and temporal scales? Are benthic processes (e.g., ecological efficiency in exploiting resources) related to spatial variability?

The deep sea is the largest ecosystem on Earth and is the largest reservoir of (yet undiscovered) biodiversity. However, most of what we know about the diversity of life on Earth comes from large-scale studies of terrestrial ecosystems (Waide et al., 1999). It is unlikely that biodiversity paradigms, evident in terrestrial ecosystems, can be applied to marine ecosystems. For instance, it is clear that on open continental slopes there is greater species richness at midslope depths (Figure 4). While changes in species and diversity do occur with increasing altitude on land, the effects on biodiversity are also related to reduction in total land area at each altitude. Such a reduction in area with increasing altitude and its effects on diversity are not apparent with increasing depth in most deepsea ecosystems.

It is not clear how high local species richness in deep-sea sediments is related to ecosystem functioning. In terrestrial ecosystems there are reports of a linear relationship between biodiversity and ecosystem functioning, but marine

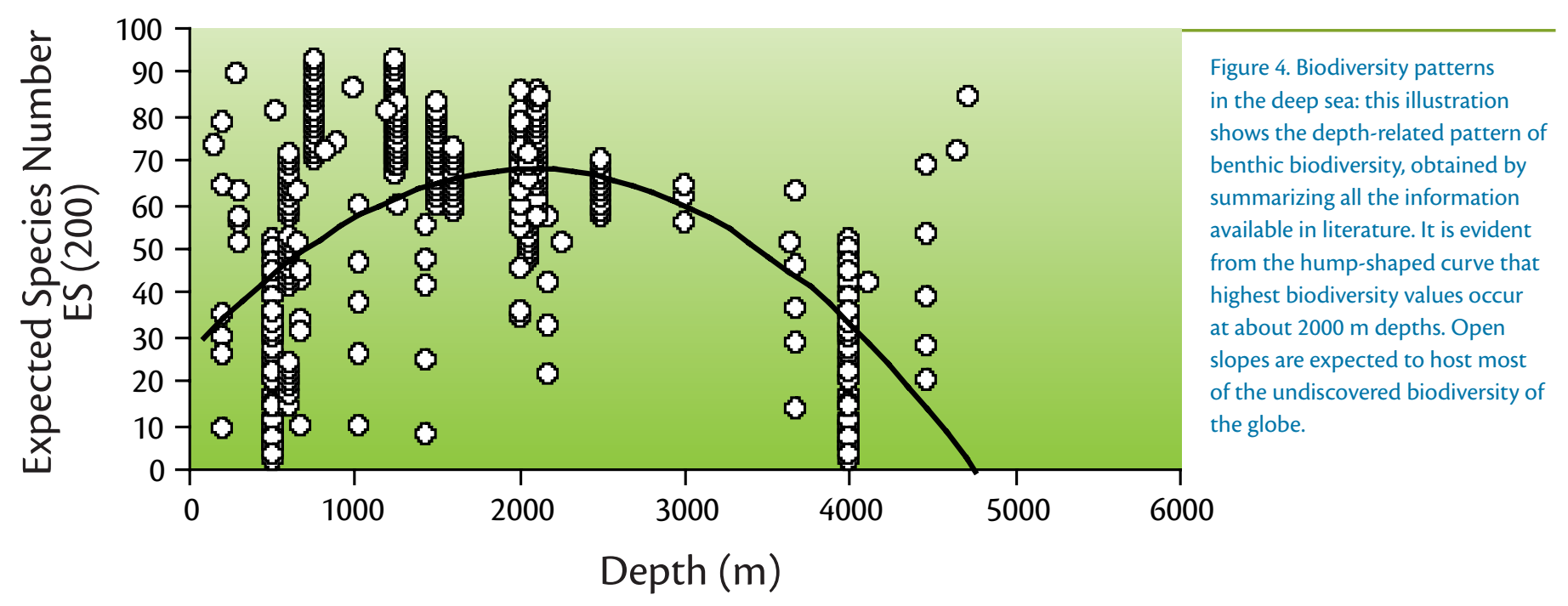


microcosm studies suggest that biodiversity peaks at intermediate levels of productivity (Kassen et al., 2000). Inverse relationships between biodiversity and ecosystem functioning have also been observed, suggesting the key role of a few species (Loreau et al., 2001). In contrast to terrestrial ecosystems, biodiversity patterns of zooplankton (i.e., consumers) in the oceans are independent from that of phytoplankton (i.e., producers) (Irigoien et al., 2004). Such differences could indicate that different ecosystems (terrestrial versus marine, coastal versus open ocean) have different relationships between diversity and ecosystem functioning. HERMES aims to address these issues in relation to continental slope sediments.

\section{INTEGRATION OF GEOSCIENCE WITH ECOSYSTEM STUDIES}

Over the past decade, marine geologists have become increasingly involved in the application of marine geoscience to biological issues, such as characterization of habitat structure and dynamics (Wefer et al., 2003). This is a direct result of significant advances in the resolution and accuracy of seabed mapping technologies as well as of underwater photo- and videography. The combination of visual and acoustic data will lead to improved understanding of complex seabed processes such as fluid flow and gas emissions. Improved techniques that will be used include high-resolution side-scan sonars, multibeam bathymetric mapping systems, precise navigation, high resolution sub-seabed profilers, precision sampling, photographic systems, and advances in digital data processing and scientific visualization procedures.

The output expected from HERMES is a

\title{
fundamental contribution to basic
}

\author{
knowledge of ocean ecosystems that will \\ inform environmental policy.
}

Newly developed bathymetry modules for ROVs can record seafloor structures down to $20-\mathrm{cm}$ scale. These data can be linked to video and photography monitoring of seafloor ecosystems. Such data enable biologists to focus their activities and to determine the extent of each habitat. These methods can also be used to develop three-dimensional visualizations of the geo-, hydro- and biospheres, providing a fully interactive knowledge base.With these tools, we will investigate the geological drivers of the ecosystems, including fluid flow, gas hydrates, sediment transport, and seabed composition. Thus, geological work mentioned in several other articles in this issue, will continue in relation to ecosystem studies.

\section{SELECTION OF STUDY SITES}

The principal work areas are shown in Figure 5, which also displays the distribution of key features (deep-water coral sites, landslides, canyons, cold seeps).

While HERMES will concentrate its research effort on a few specific sites, it aims to compare similar systems within each area, where possible, so that general principles on the interaction of biodiversity, the environment, and ecosystem functioning might be generated.

The HERMES study areas represent a range of environments:

1. The Nordic margin is a cold-water end member with environmentally stressed ecosystems from intensive exploitation by fisheries in a hydrocarbon province.

2. The Porcupine/Rockall margin is rich in giant carbonate mounds and canyon systems. Many of the carbonate mounds support luxuriant coral reefs, and a number of these areas have been, or are likely to be, designated as Special Areas of Conservation (SACs) by Irish and United Kingdom authorities.

3. The western Iberian margin has large canyon systems that have been studied in other projects such as the EU project EUROSTRATAFORM, but only from a sedimentological point of view (see other contributions in this issue). Little is known of the biology of canyon systems because of the difficulty in working in these areas. New ROV technology available in Europe will allow HERMES to explore many of the canyons for the first time. The Moroccan margin of the Gulf of Cadiz has specialist seabed communities on mud volcanoes.

4. The western Mediterranean is bounded by the sills of Gibraltar and the Sicily Channel, and has large contrasts between the strongly Atlantic-influenced southern area and the areas to the north where influence from European rivers is highly significant and has changed dramatically in just a few decades. In addition, the EUROSTRATAFORM project has provided a unique background to sedimentary processes 


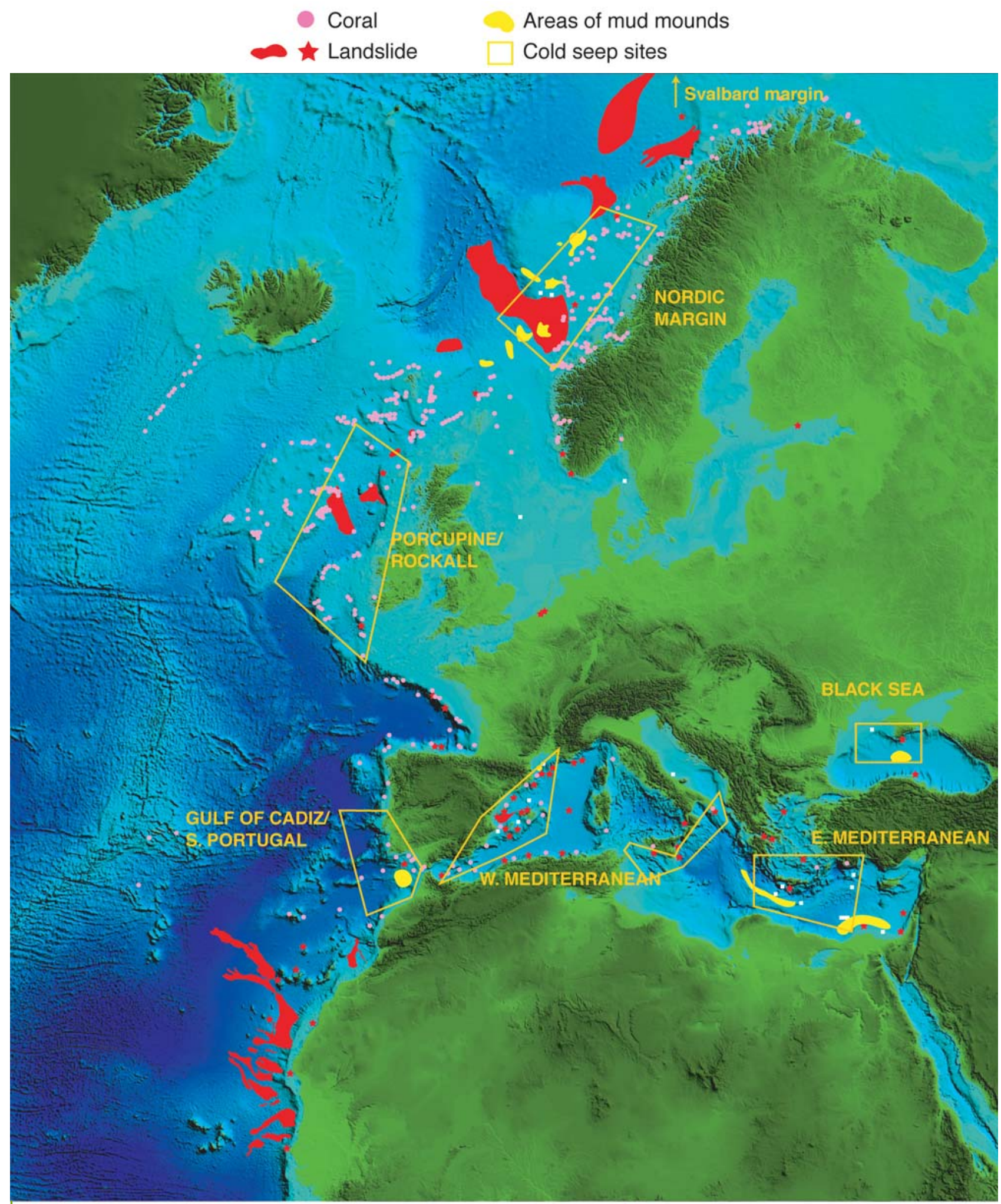

Figure 5. Map showing key study areas in the HERMES project. These areas were chosen specifically to include areas of cold-water coral (pink dots show known occurrences), landslides (red areas and red stars), areas with mud mounds (yellow areas), and areas of known fluid flow (white squares). They also include the anoxic Black Sea, low-productivity eastern Mediterranean, gateways between the East and West Mediterranean, and the West Mediterranean and Atlantic, canyoned margins of the Gulf of Lions and Portuguese margins and of the cold water, glaciated Nordic margin. 
on the slope and in the canyons.

5. The eastern Mediterranean has unique, but poorly understood, ecosystems affected by low primary productivity and by irregular events such as intermittent deep-water formation.

6. The Black Sea is a unique environment where we can study newly discovered microbial ecosystems thriving in permanent anoxia and their interaction with hydrocarbons.

\section{INTEGRATED MODELLING}

\section{LEADS TO POLICY ADVICE}

So far, marine ecosystem assessment suffers from a lack of models integrating biology into element cycles and global change issues. Mathematical models, in combination with data assimilation techniques, can be used to quantify geochemical or food-web flows; eventually, these models can provide mechanistic understanding of ecosystem functioning. When properly calibrated and validated, they provide a unique avenue for forecasting the effects of perturbations. One problem is that, until now, modelling and data-acquisition efforts were mainly developed separately. In HERMES, they will be closely coupled. The question of model uncertainty will be explicitly tackled using data assimilation tools. Where necessary, modelling will provide guidelines for acquiring new data or improving sampling, so as to constrain ill-defined processes.

The output expected from HERMES is a fundamental contribution to basic knowledge of ocean ecosystems that will inform environmental policy. Mapping the margins of Europe at a variety of resolutions is a major task. We will use integrative knowledge tools to dem- onstrate the results to scientists, policy makers, industry, and the public. These tools include thematic mapping, ecosystem, geo-visualization, and Earth system modelling, and will be used to formulate recommendations for sustainable management of ecosystems.

Management recommendations for the sustainable use of margin ecosystems, while minimizing the impacts of human activities, need to be developed and implemented. The challenge of effective offshore governance across transnational boundaries in Europe has been brought sharply into focus by the need to establish SACs to protect European deep-water corals under the EU Habitats Directive. Implementation of offshore SACs requires a three-strand approach: (1) designation of the SAC under national legislation, (2) specific action in the form of technical conservation measures under the Common Fisheries Policy where fishing activities are concerned, and (3) the development of appropriate enforcement and compliance strategies.

\section{ACKNOWLEDGEMENTS}

The authors gratefully acknowledge the wider HERMES community in the preparation of this document, and thank the European Commission for supporting this project (contract number GOCECT-2005-511234-1) under its Sixth

Framework Programme.

\section{REFERENCES}

Boetius, A., K. Ravenschlag, C.J. Schubert, D. Rivkert, F. Widdel, A. Gieseke, R. Amann, B.B. Jørgensen, U. Witte, and O. Pfannkuche. 2000. A marine microbial consortium apparently mediating anaerobic oxidation of methane. Nature 407:623-626.

Danovaro, R., A. Dell'Anno, M. Fabiano, A. Pusceddu, and A. Tselepides. 2001. Deep-sea ecosystem response to climate changes: The Eastern Mediterranean case study. Trends in Ecology and Evolution 16:505-510.
Freiwald A., J.H. Fosså, A. Grehan, T. Koslow, and J.M. Roberts. 2004. Cold-water coral reefs. UNEP-WCMC Biodiversity Series No 22. United National Environment Programme, World Conservation Monitoring Centre Cambridge, United Kingdom, 84 pp.

Irogien X., J. Huisman, and R.P. Harris. 2004. Global biodiversity patterns of marine phytoplankton and zooplankton. Nature 429:863-867.

Kassen R., A. Buckling, G. Bell, and P.B. Rainey. 2000. Diversity peaks at intermediate productivity in a laboratory microcosm. Nature 406:508-512.

Loreau, M., S. Naeem, P. Inchausti, J. Bengtsson, J.P. Grime, A. Hector, D.U. Hopper, M.A. Huston, D. Raffaelli, B. Schmid, D. Tilman, and D.A. Wardle. 2001. Biodiversity and ecosystem functioning: Current knowledge and future challenges. Science 294:804-808.

Parkes, R.J., B.A. Cragg, S.J. Bale, J.M. Getliff, K. Goodman, P.A. Rochelle, J.C. Fry, A.J. Weightman, and S.M. Harvey. 1994. Deep bacterial biosphere in Pacific Ocean sediments. Nature 371:410-413.

Rogers, A., D. Billett, W. Berger, E. Flach, A. Freiwald, J. Gage, D. Hebbeln, C. Heip, O. Pfannkuche, E. Ramirez-Llodra, L. Medlin, M. Sibuet, K. Soetaert, O. Tendal, A. Vanreusel, and M. Wlodarska-Kowalczuk. 2003. Life at the edge: Achieving prediction from environmental variability and biological variety. Pp. 387-404 in Ocean Margin Systems, G. Wefer, D.S.M. Billett, D. Hebbeln, B.B. Jørgensen, M. Schlüter, and T.C.E. van Weering, eds. Springer-Verlag, Berlin.

Sibuet, M. and K. Olu-Le Roy. 2003. Cold seep communities on continental margins: structure and quantitative distribution relative to geological and fluid venting patterns. Pp. 235-251 in Ocean Margin Systems, G. Wefer, D.S.M. Billett, D. Hebbeln, B.B. Jørgensen, M. Schlüter, and T.C.E. van Weering, eds. Springer-Verlag, Berlin.

Thomsen, L., T. van Weering, P. Blondel, R.S. Lampitt, F. Lamy, I.N. McCave, S. McPhail, J. Meinert, R. Neves, L. d'Ozouville, D. Ristow, C. Waldmann, and R. Wollast. 2003. Margin building-regulating processes. Pp. 195-203 in Ocean Margin Systems, G. Wefer, D.S.M. Billett, D. Hebbeln, B.B. Jørgensen, M. Schlüter, and T.C.E. van Weering, eds. Springer-Verlag, Berlin.

Vetter, E.W., and P.K. Dayton. 1998. Macrofaunal communities within and adjacent to a detritusrich submarine canyon system. Deep-Sea Research II 45:25-54.

Waide, R.B., M.R. Willig, C.F. Steiner, G. Mittelbach, L. Gough, S.I. Dodson, G.P. Juday, and R. Parmenter. 1999. The relationship between productivity and species richness. Annual Review Ecological Systematic 30:257-300.

Wefer, G., D.S.M. Billett, D. Hebbeln, B.B. Jørgensen, M. Schlüter, and T.C.E. van Weering, eds. 2003. Ocean Margin Systems. Springer Verlag, Berlin, $495 \mathrm{pp}$. 